\title{
Pierre Briant. [chap.] 9. Alexander and the Persian Empire, between "Decline" and "Renovation", History and Historiography
}

\section{Rémy Boucharlat}

\section{(2) OpenEdition}

1 Journals

Édition électronique

URL : http://journals.openedition.org/abstractairanica/41085

DOI : 10.4000/abstractairanica.41085

ISSN : 1961-960X

Éditeur :

CNRS (UMR 7528 Mondes iraniens et indiens), Éditions de l'IFRI

\section{Édition imprimée}

Date de publication : 1 décembre 2013

ISSN : 0240-8910

Référence électronique

Rémy Boucharlat, "Pierre Briant. [chap.] 9. Alexander and the Persian Empire, between "Decline" and "Renovation", History and Historiography », Abstracta Iranica [En ligne], Volume 32-33 | 2013, document 41, mis en ligne le 01 juillet 2016, consulté le 03 octobre 2020. URL : http://journals.openedition.org/ abstractairanica/41085; DOI : https://doi.org/10.4000/abstractairanica.41085

Ce document a été généré automatiquement le 3 octobre 2020.

Tous droits réservés 


\title{
Pierre Briant. [chap.] 9. Alexander and the Persian Empire, between "Decline" and "Renovation", History and Historiography
}

\author{
Rémy Boucharlat
}

\section{RÉFÉRENCE}

Pierre Briant. « [chap.] 9. Alexander and the Persian Empire, between "Decline" and "Renovation", History and Historiography ", in : W. Heckel, L. Trittle, eds., Alexander the Great: a new History. Oxford, Blackwell, 2009, p. 171-188.

1 Dans cet ouvrage sur Alexandre, encore - le rythme des bons et moins bons ouvrages sur le grand homme doit être annuel sinon plus rapide - les deux articles de PB ont chacun un élément original : l'un traite du dernier Achéménide, fort maltraité par les auteurs classiques et l'historiographie moderne, le symbole du "colosse aux pied d'argile". PB lui a redonné sa juste place (Darius à l'ombre d'Alexandre 2003, cf. Abs. Ir. 26, c.r. $n^{\circ}$ 87). L'autre chapitre traite d'historiographie - le grand thème de recherche de l'A. ces dernières années - proposant une analyse de la continuité de l'empire achéménide à celui d'Alexandre, en particulier dans le domaine de l'économie.

2 [Ce texte concerne également le $n^{\circ} 40$ ] 


\section{AUTEURS}

RÉMY BOUCHARLAT

CNRS, Lyon 